\title{
Evaluation of Methanol Extract of Tephrosia villosa For in vitro Anticancer and Antioxidant Potentials Against Cancer Cell Lines
}

\author{
Soma Pramanik ${ }^{1}$, Pinkey Rawal ${ }^{1}$ and Ramesh $\mathrm{C}^{2}$ \\ 1Department of Pharmaceutical Chemistry, East West College of Pharmacy, Bangalore \\ 2Department of Pharmacology, East West College of Pharmacy, Bangalore
}

Received: 12 Oct 2020 / Accepted: 6 Nov 2020/ Published online: 01 Jan 2021

*Corresponding Author Email: rameshcology80@gmail.com

\begin{abstract}
Objective: The present study was designed to evaluate methanol extract of Tephrosia villosa for anticancer against cancer and normal cells and also determine its antioxidant properties. Methods: The methanol extract of Tephrosia villosa was prepared using sox-let apparatus. The methanol extract was evaluated for its in-vitro anticancer potentials against human Vero (normal) MCF-7 (breast), HCT-116 (colon), liver (HEP-G 2 ) and A-549 (lung) cancer cell lines by MTT assay and concentration of the methanol extract required to inhibit $50 \%$ of cell growth $\left(\mathrm{IC}_{50}\right)$ was recorded. To determine antioxidant properties of the extract, Superoxide scavenging, Lipid peroxidation and DPPH methods were used and $\mathrm{IC}_{50}$ values of extracts were noted. Results: In the present study, methanol extract of Tephrosia villosa has shown anti-cancer property by exhibiting significant IC $\mathrm{C}_{50}$ values against all cancer cell lines MCF 7, HCT-116, HEP-G2 and A-549 but $\mathrm{IC}_{50}$ of methanol extract against vero cell lines was not significant. The extract has also shown significant $\mathrm{IC}_{50}$ values in Superoxide scavenging, Lipid peroxidation and DPPH methods and antioxidant activity was comparable to standard drug ascorbic acid. Conclusion: The results obtained from the present research work suggested that the methanol extract of Tephrosia villosa possess significant in vitro cytotoxic potentials against cancer cells MCF 7, HCT-116 and A-549 cell lines but cytotoxic property of extract against normal cell was not significant. The results also suggested that the methanol extract have in vitro antioxidant properties.
\end{abstract}

\section{Keywords}

Anticancer activity, Tephrosia villosa, $\mathrm{IC}_{50}$ value, MTT assay and antioxidant activity.

\section{INTRODUCTION}

Cancer is serious and common disease condition which kills peoples in the society more than infectious diseases such as tuberculosis, malaria and HIV/AIDS combined ${ }^{[1]}$. Cancer has become major health problem worldwide and claims more than 10 million people dies a year due to breast, lung, liver and colon ovarian cancers ${ }^{[2]}$. According to estimation about 12.7 million cancer cases and 7.6 million cancer deaths are reported in 2008 among which $56 \%$ of the cases and $64 \%$ of the deaths occurred in the economically developing world ${ }^{[3]}$. On the Indian scene, about 1.1 million new cancer cases reported per year which stands India as a single country among 184 countries and contributes about $7.8 \%$ of deaths to global cancer mortality figures ${ }^{[4]}$. Cancer 
has the second highest mortality rate after cardiovascular diseases throughout the world. Even though remarkable progress has been made by medical science, the availability of safe and specific anticancer drugs has remained a major challenge in clinical practice ${ }^{[5,6]}$. Although the cancer research has led to a number of new and effective solutions, the medicines used as treatments have clear limitations and unfortunately cancer is projected as the primary cause of death in the future ${ }^{[7,8]}$. Antioxidants are a group of substances that are useful for fighting cancer and other processes that potentially lead to diseases such as atherosclerosis, Alzheimer, Parkinson, diabetes, and heart disease. Antioxidants act by preventing the onset of cancer during carcinogenesis and they are generally beneficial to cells ${ }^{[9]}$.

Medicinal plants have been used since ancient time in Ayurveda and other traditional medicine system and their utility has been increasing day by day throughout world. Natural compounds obtained from herbs are considerably safe and effective than synthetic compounds. Moreover, the problem of development of drug less compared to synthetic drugs. is also reduced. The herbal drugs comprise a major source of anticancer medicine due to presence of various phyto-constituents such as vincristine, vinblastine, taxanes, camptothecines and in developed countries and developing countries ${ }^{[9]}$. The free radicals are the main agents which induces mutation by damaging cellular DNA ultimately leads to development of cancers in the body. Hence much attention has been given on the development of anticancer agents that possess antioxidant property due to their free radical scavenging potential which plays an important role in protection of DNA free radical mediated damage ${ }^{[10]}$.

The Tephrosia is a genus of plant which is of Indian and several species of Tephrosia are medicinally important and have used in ayurveda for the treatment of ailments ${ }^{[11]}$. The Tephrosia villosa belongs to this genus frequently used as traditional and folklore medicine for the management various health complications such as ulcer, diabetes, urinary disorders, liver diseases and cancer ${ }^{[12]}$. Though this plant used essentially in traditional medicine for cancer, it has lack of scientific evidence. Hence it was necessary to provide a clear background proof for the beneficial property of the plant in cancer. In this attempt, the study had been conducted to determine in vitro antioxidant and anticancer potentials of methanol extract of Tephrosia villosa.

\section{MATERIALS AND METHODS}

\section{Plant material}

The areal parts of plant Tephrosia villosa have been collected from the surroundings of Sri Venkateshwara university, Tirupati, India and dried under shade. The plant material was identified and authenticated by Dr. Madhava chetty Asst.Prof., Department of Botany Sri Venkateshwara university, Tirupati and specimen herbarium was preserved at institute herbarium library (Herbarium number-986). The aerial parts of plant were separated from other parts, washed, cleaned and dried under shade for further use.

\section{Preparation of extract}

The shade dried plant material was pulverised into powder and passed through sieve No. 22 mesh. About $350 \mathrm{~g}$ (appx.) of coarse powder was subjected to successive solvent extraction using petroleum ether and methanol in soxhlet's apparatus [13]. The percentage yield of methanol extract was found to be 14.22 .

\section{Preliminary phytochemical investigation}

The preliminary phytochemical investigation for the methanolic extract of Tephrosia villosa had been conducted as per procedure prescribed by Khandelwal ${ }^{[14]}$.

\section{Drugs and chemicals}

All reagents and chemicals used in the study were obtained commercially and were of analytical grade. The standard drugs tamoxifen and paclitaxel were obtained as gift samples from Strides laboratories, Bangalore.

\section{Evaluation of antioxidant property}

The evaluation of antioxidant activity of methanol extract of Tephrosia villosa was carried out by the following two methods:

\section{Lipid peroxidation method}

Lipid peroxidation inhibition was estimated by the formation of colored product in the reaction mixture. The assay mixture contained the methanol extract in various concentrations, to which were added $0.1 \mathrm{ml}$ of potassium chloride $(30 \mathrm{mM}), 0.1 \mathrm{ml}$ of ascorbic acid $(0.06 \mathrm{~mm})$ and $0.1 \mathrm{ml}$ of ammonium ferrous sulphate $(0.16 \mathrm{mM})$ in succession. Later the reaction mixture was treated with $0.2 \mathrm{ml}$ of sodium dodecyl sulphate (8.1\%), $1.5 \mathrm{ml}$ of thiobarbituric acid $(0.8 \%)$ and $1.5 \mathrm{ml}$ of $20 \%$ acetic acid $(\mathrm{pH} \mathrm{3.5)}$ and then $5 \mathrm{ml}$ of $15: 1 \mathrm{v} / \mathrm{v}$ butanol-pyridine mixture was added. The absorbance of the organic layer containing the thiobarbituric acid reactive substances (TBARS) was measured at $532 \mathrm{~nm}^{[15]}$.

\section{DPPH radical scavenging activity}

The free radical scavenging activity was measured in terms of hydrogen donating or radical scavenging ability, using the stable radical, DPPH. About $0.1 \mathrm{mM}$ 
solution of DPPH in methanol was prepared and $1 \mathrm{ml}$ of this solution was added to $3 \mathrm{ml}$ of the different concentration of ethanolic extract $(50-400 \mu \mathrm{g} / \mathrm{ml})$ in different test tubes. The mixture was shaken and allowed to stand at room temperature for $30 \mathrm{~min}$ and the absorbance was measured at $517 \mathrm{~nm}$ using a spectrophotometer. Decrease in absorbance of the reaction mixture indicates higher free radical scavenging activity ${ }^{[16]}$.

Superoxide scavenging activity.

This method carried out by using Nitro blue tetrazolium (NBT) reagent, the method is based on generation of super oxide radical (O2-) by auto oxidation of hydroxylamine hydrochloride in presence of NBT, during the reaction the NBT is reduced to nitrite. In brief, aliquots of 0.1 to $1.0 \mathrm{~mL}$ to ascorbic acid solution were taken in a test tube, to which $1 \mathrm{~mL}$ of sodium carbonate, $0.4 \mathrm{~mL}$ of NBT and $0.2 \mathrm{~mL}$ of EDTA were added and zero-minute reading was taken at $560 \mathrm{~nm}$. The reaction was initiated by the addition of $0.4 \mathrm{~mL}$ of hydroxylamine hydrochloride to the above solution. Reaction mixture was incubated at $25^{\circ} \mathrm{C}$ for 5 mins; the reduction of NBT was measured at $560 \mathrm{~nm}$. A parallel control was also treated in the similar manner. The methanol extract was treated in the similar manner, absorbance was recorded and $\mathrm{IC}_{50}$ values was calculated ${ }^{[16]}$.

\section{Evaluation of anticancer activity Procurement of cell lines}

In-vitro anticancer activity for methanol extract was evaluated by MTT assay against MCF-7, HCT-116, HEP-G2, A-549 cells and Vero cell lines. The following cells were obtained from NCCS, Pune and subculture under suitable conditions ${ }^{[17,18]}$.

- Vero-Normal human cells.

- MCF-7 - human breast adenocarcinoma cell line first isolated in 1970 from the breast tissue of 69 year old Caucasian women.

- HCT-116 - human colon carcinoma cell line.

- HEP-G2 - human hepatocellular liver carcinoma cell line.

- A-549 - adenocarcinomic human alveolar basal epithelial cell line.

MTT (3-(4,5-Dimethylthiazol-2-YI)-2,5-

Diphenyltetrazolium Bromide) assay

The cytotoxicity of TVME against MCF-7, HCT-116, HEP-G2, A-549 and vero cells was determined by the MTT (3-(4,5-Dimethylthiazol-2-YI)-2,5Diphenyltetrazolium Bromide) assay [17,18]. Exponentially growing cells were harvested from
$25 \mathrm{~mL}$ flask and a stock cell suspension was prepared. Cells ( 1 ラ 105/well) were plated in 100 オ I of medium well in 96-well plates (Costar Corning, Rochester, NY). After 48 hours incubation the cell reaches the confluence. Then cells were incubated in the presence of various concentrations of the TVME and standard drugs in $0.1 \%$ DMSO for $48 \mathrm{~h}$ at $37-\mathrm{C}$. The tamoxifen was used reference drugs for the breast cancer cell lines and paclitaxel was used standard drugs for other cell lines. After removal of the sample solution and washing with phosphate-buffered saline (pH7 .4), 20 才 l/well (5 mg/ml) of $0.5 \% 3-(4,5-$ dimethyl-2-thiazolyl)-2, 5-diphenyl-tetrazolium bromide cells (MTT), phosphate-buffered saline solution was added. After $4 \mathrm{~h}$ incubation, $0.04 \mathrm{M} \mathrm{HCl}$ isopropanol was added. Viable cells were determined by the absorbance at $450 \mathrm{~nm}$. Measurements were performed and the concentration required for a $50 \%$ inhibition of viability was determined graphically. The absorbance at $450 \mathrm{~nm}$ was measured with a UVSpectrophotometer using wells without sample containing cells as blanks. The effect of the samples on the proliferation of cells was expressed as the \% cell viability, using the following formula: \% cell viability $=$ A450 of treated cells / A450 of control cells 亏 $100 \%$.

The percentage growth inhibition was calculated using the following formula.

$\%$ growth inhibition $=\{100-$

( $\left.\left.\frac{\text { mean absorbance of individual test group }}{\text { Mean absorbance of control group }}\right) \times 100\right\}$

The IC50 value obtained is the concentration of sample required to inhibit the growth of $50 \%$ of viable cell population.

\section{RESULTS}

\section{Preliminary phytochemical investigation}

The percentage yield of the TVME was found to be $8.19 \% \mathrm{w} / \mathrm{w}$. The preliminary phyto-chemical investigation for the methanol extract of Tephrosia villosa reveals the presence of poly phenols, flavonoids, tannins, steroids, alkaloids and carbohydrates.

\section{Determination of in-vitro antioxidant activity DPPH method}

In DPPH assay, the methanol extract of Tephrosia villosa significantly decreased the absorbance produced by the DPPH and it was found to possess significant $I C_{50}$ value which was comparable to that of standard drug ascorbic acid (See Table No.1). 
Table No.1: Effect of methanol extract of Tephrosia villosa (TVME) on, DPPH, Lipid peroxidation and Superoxide scavenging methods.

\begin{tabular}{llll}
\hline Sample $(\mu \mathrm{g} / \mathrm{ml})$ & \multicolumn{3}{c}{$\mathrm{I.C50}(\mu \mathrm{g} / \mathrm{ml})$} \\
\cline { 2 - 4 } & DPPH method & Lipid Peroxidation & Superoxide Scavenging \\
\hline Ascorbic acid & $6.603 \pm 3.528$ & $7.0367 \pm 1.0707$ & $38.332 \pm 0.451$ \\
TVME & $29.24 \pm 3.060$ & $23.51 \pm 3.659$ & $53.112 \pm 1.03$ \\
\hline \multicolumn{3}{c}{ All the values are expressed as Mean \pm SEM, $\mathbf{n}=\mathbf{6}}$.
\end{tabular}

Table No.2: Effect of methanol extract of Tephrosia villosa (TVME) on, DPPH, Lipid peroxidation and Superoxide scavenging methods.

\begin{tabular}{llll}
\hline Sample $(\mu \mathrm{g} / \mathrm{ml})$ & & \multicolumn{2}{c}{ I.C50 $(\mu \mathrm{g} / \mathrm{ml})$} \\
& DPPH method & Lipid Peroxidation & Superoxide Scavenging \\
\hline Ascorbic acid & $6.603 \pm 3.528$ & $7.0367 \pm 1.0707$ & $38.332 \pm 0.451$ \\
TVME & $25.33 \pm 5.270$ & $59.596 \pm 6.846$ & $27.81 \pm 1.88$ \\
\hline
\end{tabular}

All the values are expressed as Mean \pm SEM, $n=6$.

Table No.3: IC 50 Values of methanol extracts of Tephrosia villosa against cancer and normal cells

\begin{tabular}{llllll}
\hline \multirow{2}{*}{ Treatment } & \multicolumn{5}{c}{ IC50 Values } \\
\cline { 2 - 6 } & MCF-7 & HCT-116 & HEP-G2 & A-549 & Vero \\
\hline Tamoxifen & 25.802 & -- & -- & -- & -- \\
Cyclophosphamide & -- & 41.182 & 33.565 & 38.479 & 89.235 \\
TVME & 340 & 302.42 & 345.192 & 247.27 & 1989.458 \\
\hline
\end{tabular}

\section{Lipid Peroxidation}

The antioxidant property of methanol extract of Tephrosia villosa was compared with the standard Ascorbic acid. In lipid peroxidation assay, the TVME and ascorbic acid have significantly inhibited of lipid peroxidation by decreasing the absorbance of the supernatant, The IC $\mathrm{C}_{50}$ value of TVME was comparable to that of ascorbic acid (See Table No.1)

Superoxide scavenging activity.

In superoxide free radical scavenging activity, TVME has offered good antioxidant activity by decreasing the absorbance due to NBT by exhibiting significant IC50 value which was comparable to ascorbic acid (See Table No.1).
Evaluation of in-vitro anticancer activity by MTT assay

The cytotoxic activity of the methanol extract of Tephrosia villosa on vero, MCF-7, HCT-116, HEP-G2 and A-549 cells was investigated in vitro 3-(4) 5Dimethyl-thiazol-Zyl) - 2,5 biphenyl tetrazolium bromide (MTT).

MTT assay against MCF-7 cells

The significant growth inhibition was observed due to presence of standard drug Tamoxifen and TVME of breast cancer cell lines in a study performed to determine the anticancer property of TVME against breast cancer cell lines, the methanol extract of Tephrosia villosa has shown percentage of inhibition at $500 \mu \mathrm{g} / \mathrm{ml}$ was 79.864 and. Both Tamoxifen and TVME a have exhibited the significant $\mathrm{IC}_{50}$ values (Figure No.1 and Figure No.2).

Figure No.1: The percentage inhibition of growth of MCF-7 by Tamoxifen

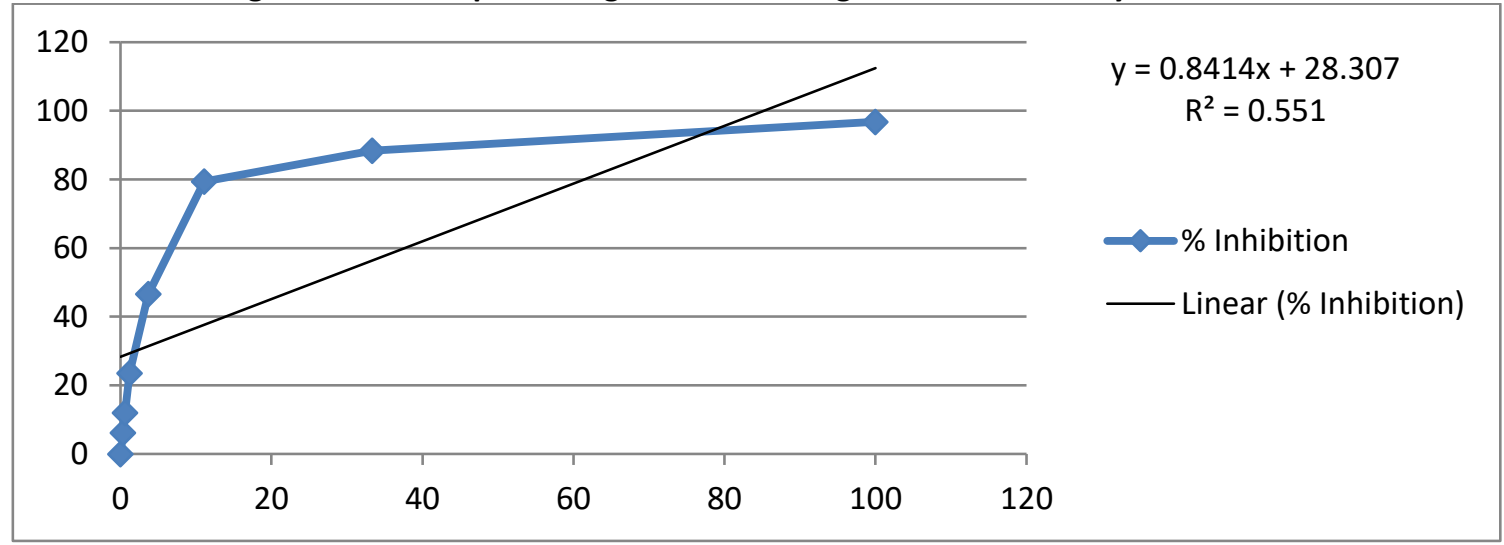


Figure No.2: The percentage inhibition of growth of MCF-7 by TVME.

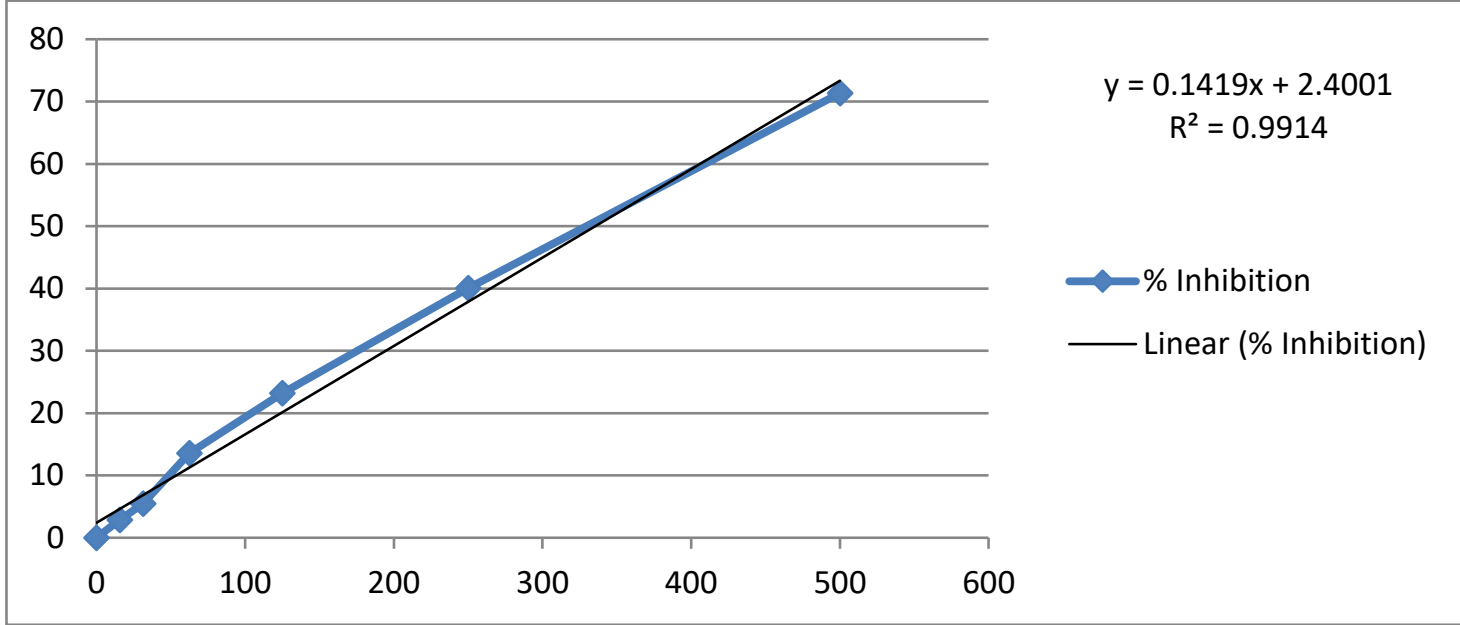

Figure No.3: The percentage inhibition of growth of HCT-116 by Cyclophosphamide

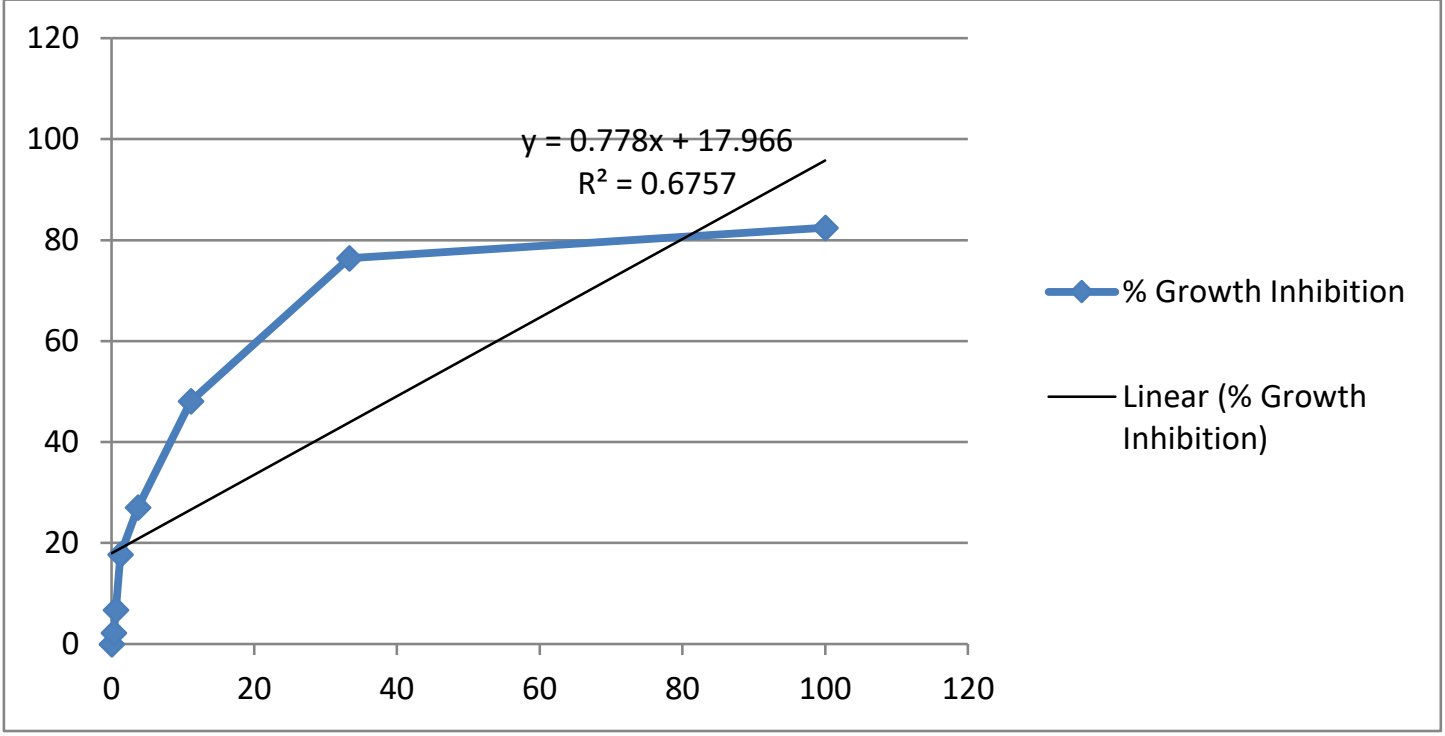

Figure No.4: The percentage inhibition of growth of HCT-116 by TVME.

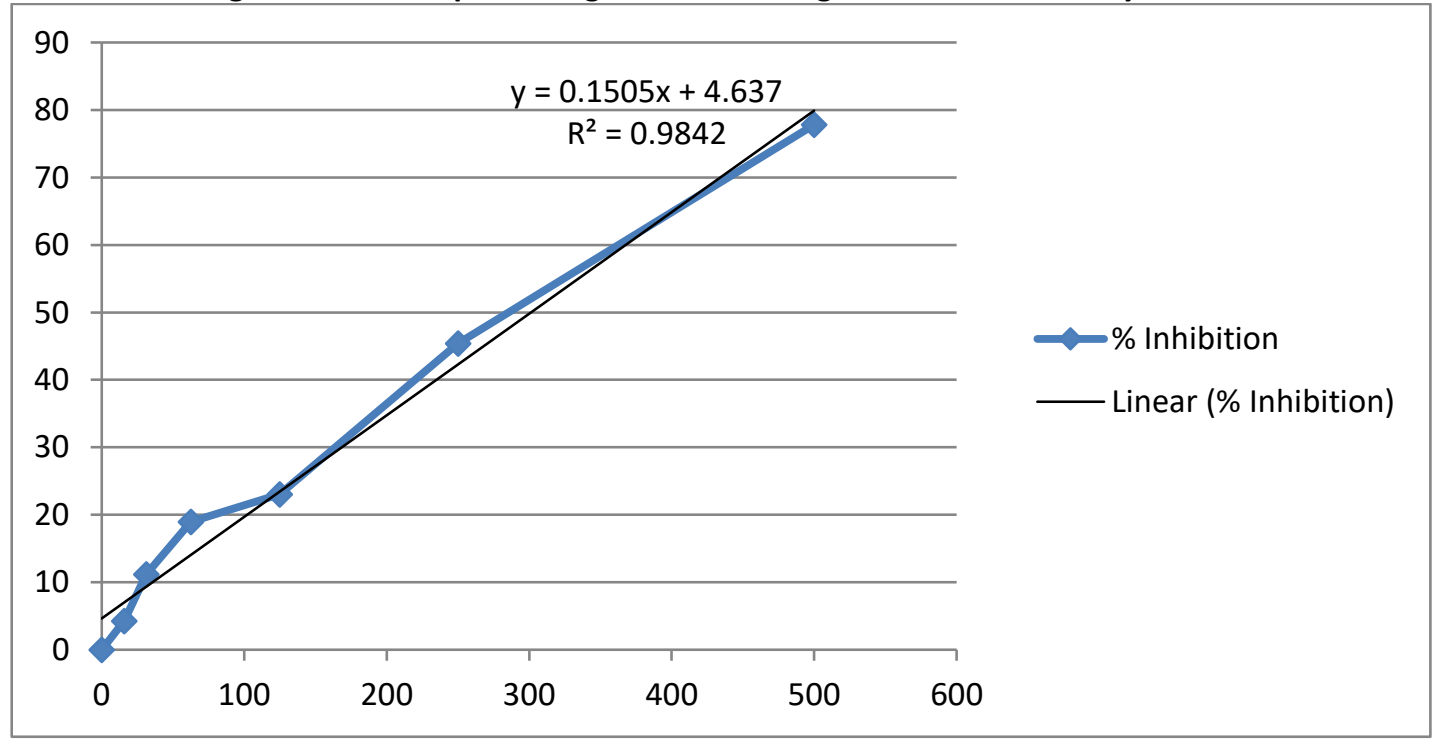


Figure No.5: The percentage inhibition of growth of HEGP-G2 by Cyclophosphamide

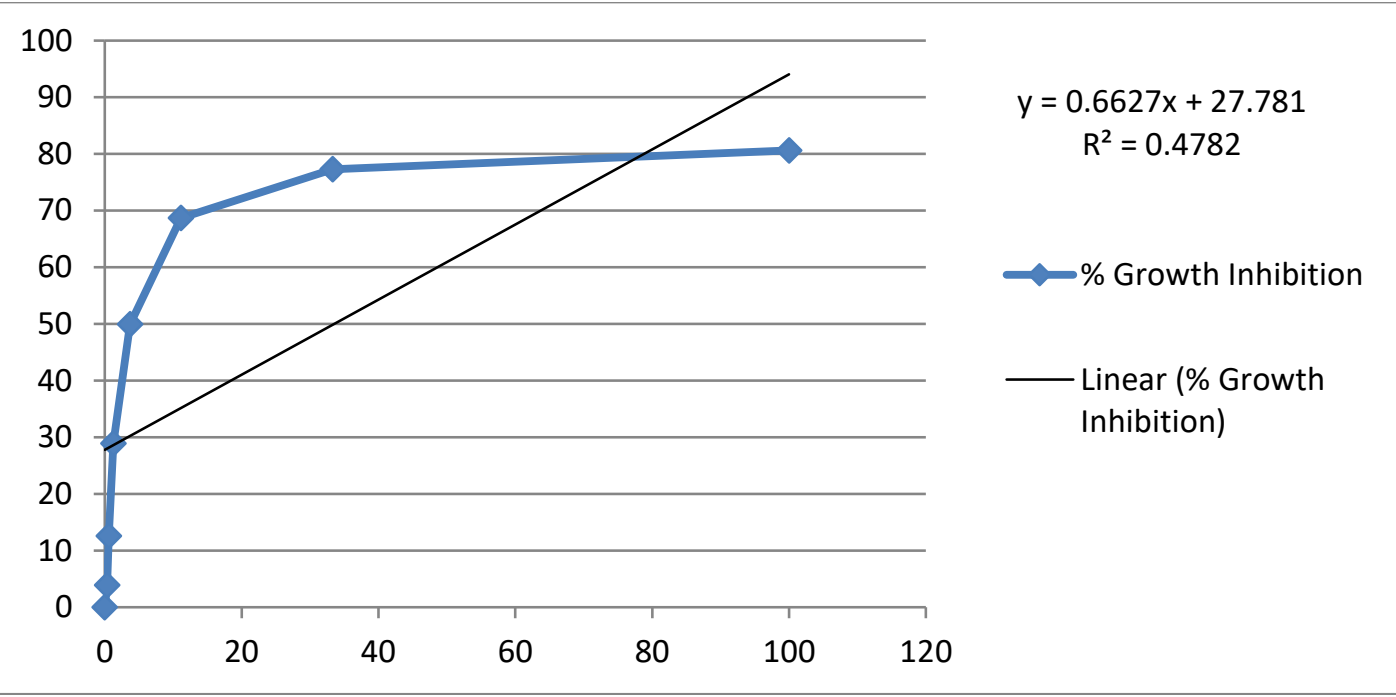

Figure No.6: The percentage inhibition of growth of HEGP-G2 by TVME.

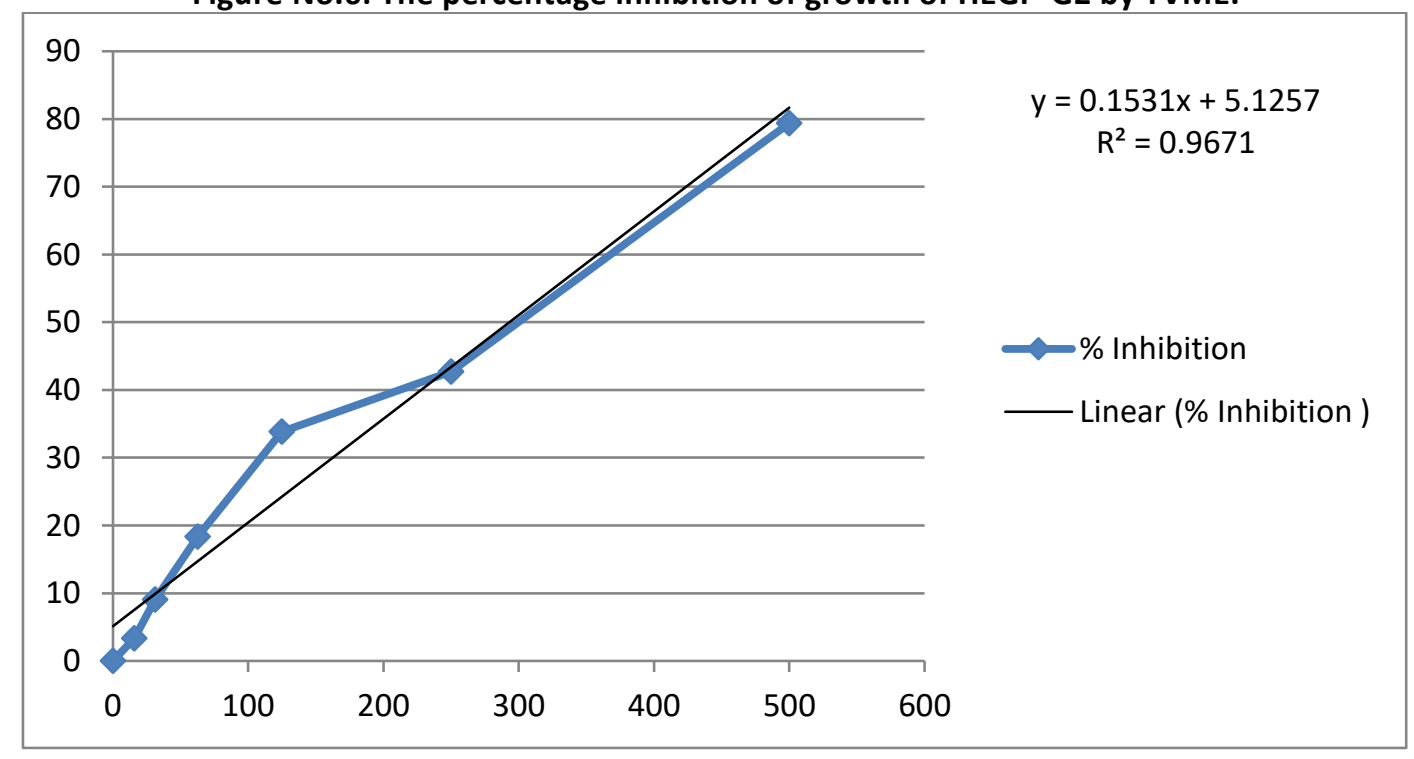

Figure No.7: The percentage inhibition of growth of A-549 by Cyclophosphamide

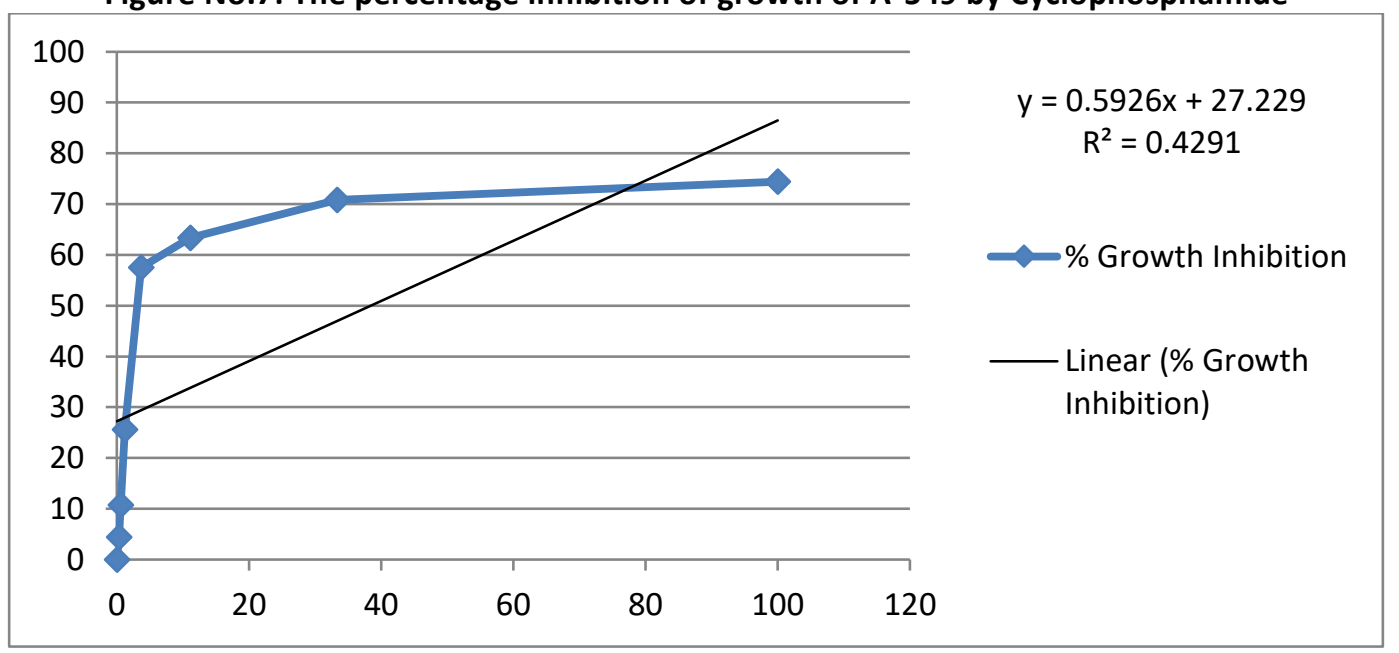


Figure No.8: The percentage inhibition of growth of A-549 by TVME.

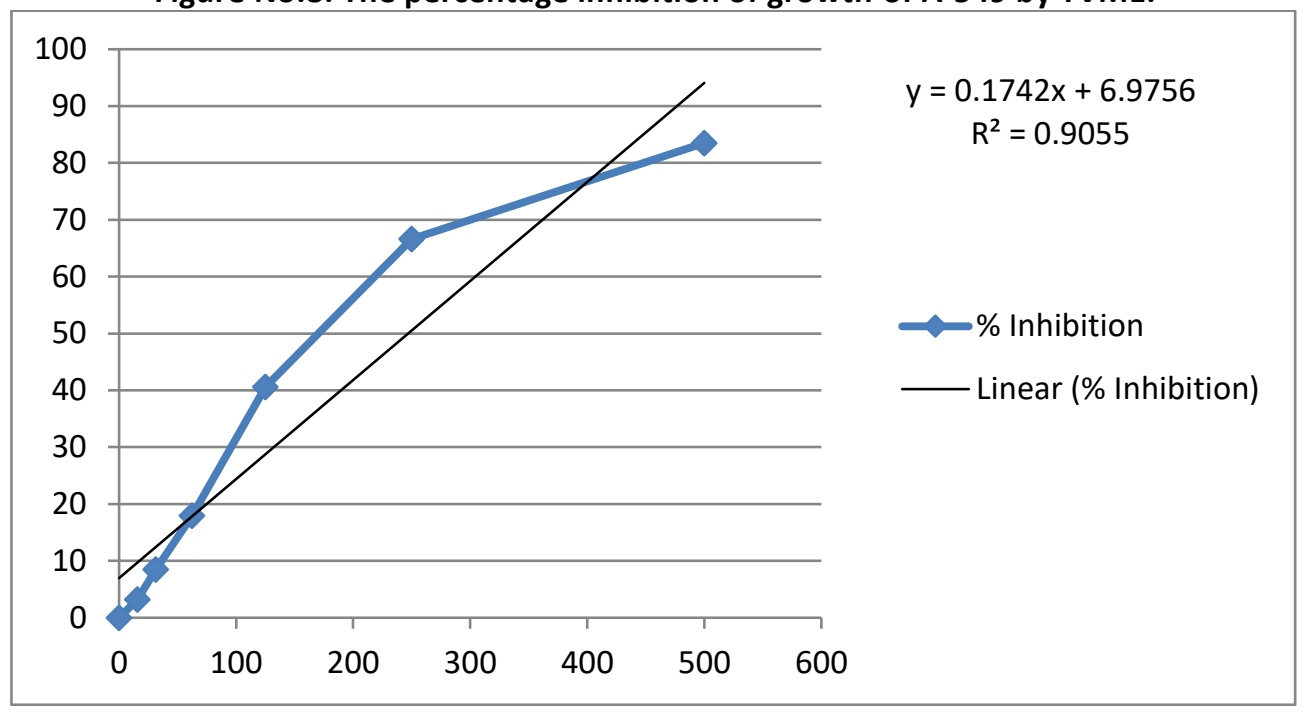

Figure No.9: The percentage inhibition of growth of Vero by Cyclophosphamide

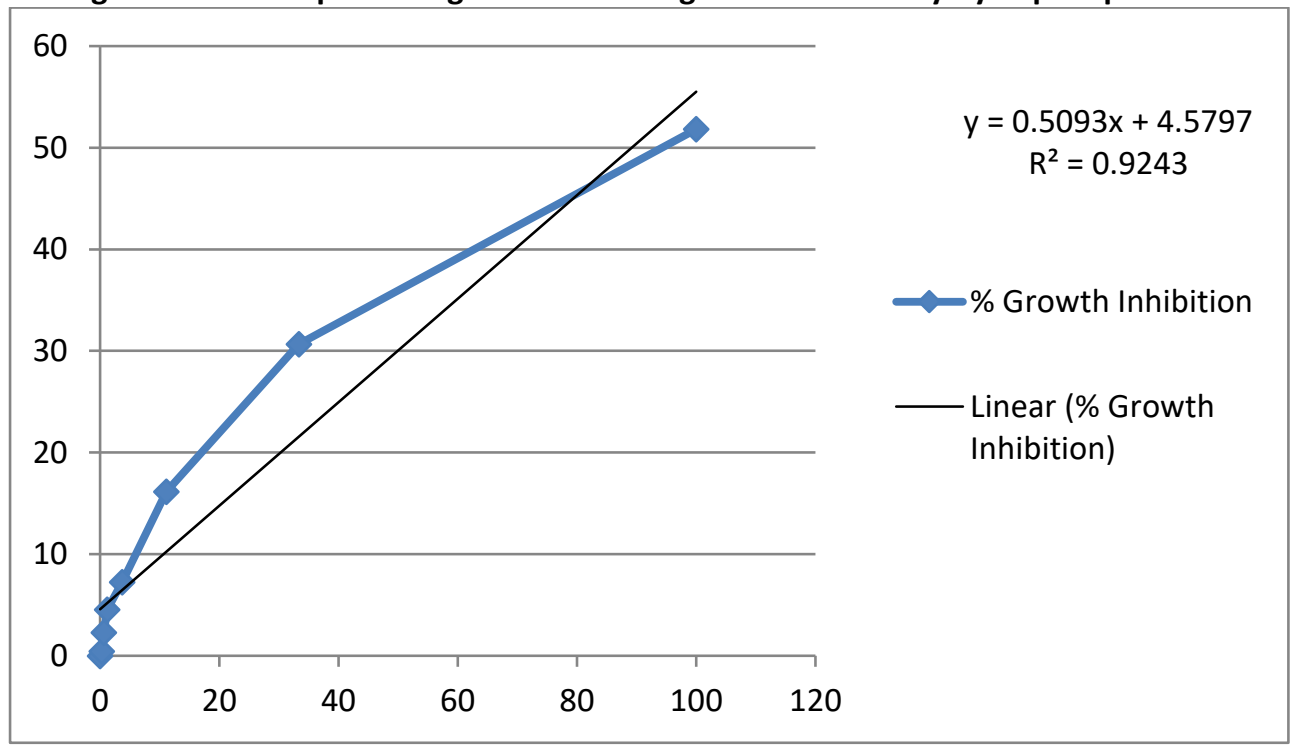

Figure No.10: The percentage inhibition of growth of Vero by TVME.

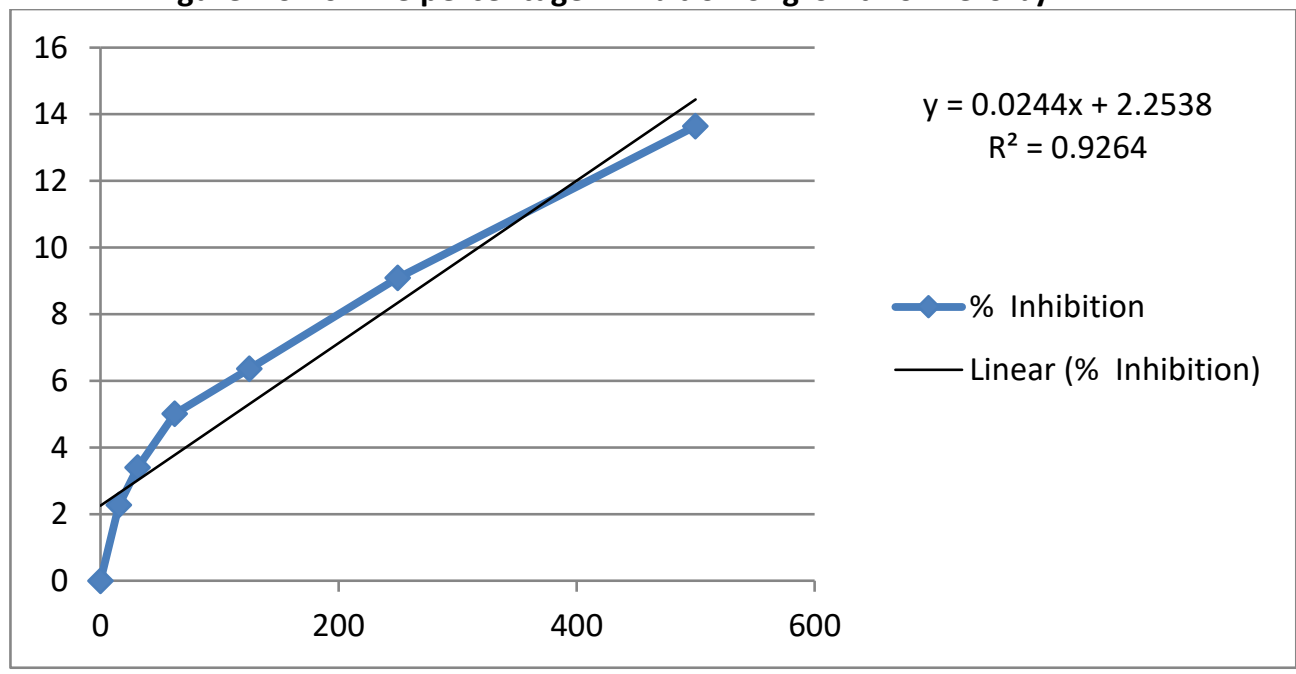


MTT assay against HCT-116 cells

The growth of colon cancer cells (HCT-116) was significantly reduced by standard drug Cyclophosphamide and TVME. The maximum percentage of inhibition of TVME was $77.8 \%$ at $500 \mu \mathrm{g} / \mathrm{ml}$. The $\mathrm{IC}_{50}$ value of TVME against HCT-116 cell lines was significant and it was comparable to standard drug Cyclophosphamide (See Table No.2).

\section{MTT assay against HEP-G2 cells}

In this study performed to assess determination of anticancer activity of TVME against human liver cancer cells extract has shown significant inhibition of the cell growth and the percentage of inhibition at $500 \mu \mathrm{g} / \mathrm{ml}$ was 79.38 . The samples treated with methanol extract of Tephrosia villosa and standard drug Cyclophosphamide have shown significant $\mathrm{IC}_{50}$ values which indicates the cytotoxic potentials of the TVME against liver cancer (See Table No.1).

\section{MTT assay against A- $\mathbf{5 4 9}$ cells}

The methanol extracts of Tephrosia villosa and Cyclophosphamide have also shown significant cytotoxic potentials against lung cancer cells and percentage of inhibition of cell growth observed for TVME at $500 \mu \mathrm{g} / \mathrm{ml}$ was 83.509 with significant $I_{50}$ value in the present study. The results of TVME were comparable to that of Cyclophosphamide a reference standard used in the research work. This also shows usefulness of the extract in treating lung cancer (see Table No.3).

\section{MTT assay against Normal human cells (Vero)}

In present research work the methanol extract of Tephrosia villosa have not shown significant cytotoxicity against normal cells. The $\mathrm{IC}_{50}$ value was more than $1000 \mu \mathrm{g} / \mathrm{ml}$ (see Table No.3)

\subsection{DISCUSSION}

Natural products have been regarded as important sources that could produce potential chemotherapeutic agents. Plant derived compounds: in particular have gained importance in anticancer therapy and some of the new chemotherapeutic agents currently available for use include paclitaxel, vincristine, podophyllotoxin and camptothecin, a natural product precursor from water soluble derivatives $[19,20]$. Several epidemiological surveys have shown that a diet rich in vegetables and fruits might give protection against tumors by mechanisms that have not been well established yet but probably due to their antioxidant activity. In recent years, naturally occurring plant substances have been getting increased scope for the intervention of malignant invasive progression in the late stage of cancer diseases ${ }^{[21,22,23]}$. Based on this knowledge, certain foods including vegetables, fruits and grains, as well as phyto-constituents of diversified pharmacological properties have been shown to provide a significant protection against various cancers ${ }^{[24,25,26]}$. Furthermore, there is an increased scope to establish scientific basis on use herbal agents for the management cancers and humans around the globe probably discovered natural remedies against disease and cancer by trial and error over the millennia ${ }^{[27]}$. Although there are some new approaches to drug discovery, such as combinatorial chemistry and computer based molecular modeling design, none of them can replace the importance of natural products in drug discovery and development. Medicinal plants have long been used to prevent and treat many diseases, including cancer due to their antioxidant potentials and thus they are good candidates for the development of anti-cancer drugs ${ }^{[28,29]}$. In this regard the study was performed to evaluate the anticancer potentials of the methanol extract of Tephrosia villosa against human normal, breast, colon, liver and lung cancer cell lines.

MTT [3-(4, 5-dimethyl thiazol-2-yl)-2, 5-diphenyl tetrazolium bromide] is taken up by the viable cells and reduced to formazan by enzyme succinatetetrazolium reductase system that belongs to the mitochondrial respiration chain functioning in metabolically active cells. Formazan formed, is a purple coloured water-insoluble product that is largely impermeable to cell membranesand hence resulting in its accumulation within the healthy cells. Hence intensity of purple color and absorbance depends on dead cells. In the present study, we used 4 types of human cancer cells for the evaluation of in-vitro cytotoxicity potentials; they are MCF-7 (breast cancer), HCT-116 (colon cancer), HEP-G2 (liver cancer) and A-549 (lung cancer) cell lines. The methanol extract was evaluated by MTT assay against all cell lines. The concentration of extract that required toreduce $50 \%$ of absorbance $\left(I_{50}\right)$ was recorded against each cancer cells ${ }^{[18,30]}$.

Human breast cancer cells are estrogen receptor (ER)-dependent and carries the wild type tumour suppressor p53 gene [31]. The Tamoxifen is an estrogen receptor antagonist used to treat the breast cancer was used in this study as a reference standard drug. The study revealed that the methanol extract prepared from the Tephrosia villosa obtained was effective in attenuating the viable tumor cell count in dose dependent manner and shown significant IC50 value which was comparable to results of standard tamoxifen.

MTT assay was performed to determine in-vitro anticancer potentials of methanol extract against colon, hepatic and lung alveolar cancer cells using Cyclophosphamide as reference standard. We found 
that the TVME significantly caused cytotoxicity against all the three cancer cell lines probably by inducing apoptosis. The $\mathrm{IC}_{50}$ values of TVME against all three, i.e, HCT-116, HEP-G2 and A-549 were significant and results comparable to standard.

But in MTT assay for the methanol extract against human normal cells, the treatment with TVME could not show significant cytotoxicity as the $I_{50}$ value is more than $500 \mu \mathrm{g} / \mathrm{ml}$. This indicates the advantage of the extract compared to presently available anticancer drugs which possess serious adverse effects.

According to rule if the crude extract is showing $\mathrm{IC}_{50}$ value less than $1 \mathrm{mg} / \mathrm{mL}(1000 \mu \mathrm{g} / \mathrm{mL})$ against MTT assay, then it can be concluded that the plant extract possesses significant cytotoxic property [32,33]. In the present study, methanol extract has shown IC50 values against all the cancer cell lines below $500 \mu \mathrm{g} / \mathrm{mL}$ and hence considered as significant values though they are many times more than synthetic standard drugs Tamoxifen and Cyclophosphamide.

In the evaluation of antioxidant activity, methanol extract of Tephrosia calophylla has shown significant antioxidant property by exhibiting significant $\mathrm{IC}_{50}$ values against all the three in vitro models.

The Tephrosia villosa was essential component of Ayurveda a traditional medicinal system of medicine due to presence of various phyto-constituents for the treatment of various health complications such as diabetes mellitus, ulcers, liver diseases, urinary disorders, cancers etc. ${ }^{[11,12]}$. In the present study the methanol extract was proven for its effective antioxidant potentials which is the important mechanism required for the anticancer activity $[34,35,36]$.

\subsection{CONCLUSION}

The methanol extract also shows the significant cytotoxicity against various cancer cells while normal cells were not affected by the extract. But further detailed study is necessary to correlate the antioxidant and cytotoxic effects of the extract.

\section{CONFLICT OF INTEREST}

All authors are hereby declaring that there is no conflict of interest with respect to manuscript.

\section{ACKNOWLEDGEMENTS}

The authors of manuscript are thankful to the principal and management of East West College of Pharmacy, Bangalore for providing facilities to conduct this research work.

\subsection{REFERENCES}

1. Singh SK, Hawkins C, Clarke ID, Squire JA, Bayani J, Hide T, Henkelman RM, Cusimano MD, Dirks PB.
Identification of human brain tumour initiating cells. Nature. 2004;18;432(7):396-401.

2. Abidemi JA, Zahoor W, Girish M, Sadhana S, Flora RA, Naresh S, Olufunmilayo OA, Dilip MM. Anticancer activity of Aristolochia ringens Vahl. (Aristolochiaceae). J Trad Com Med 2015; 5: 35-41.

3. Dhananjaya S and Aparna K. current status of cancer burden: Global and Indian scenario. Biomed Res J 2014; 1(1): 1-5.

4. G.B. Kavishankar, N. Lakshmidevi,S. Mahadeva Murthy, H.S. Prakash,S.R. Niranjana. Diabetes and medicinal plants-A review. Int J Pharm Biomed Sci 2011; 2(3): 65-80.

5. Nitesh K, Isha D, P. Vasanth R, B.S. Jayashree, Vipan P, S.N. Manjula, Seeja T, N. Gopalan K, C. Mallikarjuna R. Preliminary investigation of cytotoxic potentialof 2quinolone derivatives using in vitro and in vivo (solid tumor and liquid tumor) models of cancer. Arabian J Chem 2014; 7: 409-17.

6. Sankappa RU, A.M. Isloor, P. Shetty, K.S.R. Pai , H.K. Fun. Synthesis and in vitro biological evaluation of newpyrazole chalcones and heterocyclic diamides as potential anticancer agents. Arabian J ChemVolume 2015; 8(3): 317-21.

7. Thirumal M, Kishore G, Prithika R, Das S, Nithya G. In vitro anticancer activity of Tecoma stans (L) ethanolic leaf extract on human breast cancer cell line (MCF-7). Int J Pharm Chem Biol Sci 2012; 2(4): 488-93.

8. Valko M, Leibfritz D, Moncol J, Cronin MT, Mazur M, Telser J. Free radicals and antioxidants in normal physiological functions and human disease. Int J Biochem Cell Biol 2007; 39: 44-84.

9. Aboul-Enein AM, Abu-Elalla F, Shalaby EA, El-Shemy HA. Traditional medicinal plants research in Egypt: studies of antioxidant and anticancer activities. J Med Plants Res 2012; 6(5): 689-703.

10. Joy PP, Thomas J, Samuel Mathew, Baby P Skaria, Medicinal plants, Kerala Agricultural University, Kerala, India 1998; 1-9.

11. Baranwal A, Mazumder A, Chakraborthy GS and Gupta S. Phytopharmacological uses of Tephrosia purpurea a review. Pharmacophore 2014;5(4): 658-65.

12. Saad T, Muhammad AS, Muhammad A. A Review on the Phytochemistry and Pharmacology of Genus Tephrosia. Phytopharmacol 2013;4(3): 598-637.

13. GL Viswanatha, Santosh Kumar V, Ramesh C, Nandakumar $\mathrm{K}$ and Srinath R. Antioxidant and antimutagenic activities of bark extract of Terminalia arjuna. Asian Pac. J Trop. Med.2010; 8:412-420

14. Kokate CK. Practical Pharmacognosy. Vallabh Prakashan New Delhi: 1994;4:110-1.

15. Khandelwal KR, Practical Pharmacognosy-techniques and experiments. Pune; Nirali Prakashan; 2000.

16. Kai M, Klaus HV, Sebastian L, Ralf H, Andreas R, UlfPeter $\mathrm{H}$. Determination of DPPH radical oxidation caused by methanolic extracts of some microalgal species by linear regression analysis spectrophotometric measurements. Sensors 2007; 7: 2080-95.

17. Rajbir S, Saroj A. In vitro evaluation of peroxyl radical scavenging capacity of water extract/fractions of 
Acacia nilotica (L.) Willd. Ex Del. African J Biotechnol 2009; 8 (7): 1270-2.

18. Rupachandra S and Sarada DVL. Anticancer activity of methanol extract of the seeds of Borreria hispida and Momordica dioica. J pharmacy res. 2013;6: 565-8.

19. Mc Govern et al. Anticancer activity of botanical compounds in ancient, fermented beverages (Review). International J Oncology 2010; 37: 5-14.

20. Shankar S, Ganapathy S, Hingorani SR, Srivastava RK. EGCGG inhibits growth, Ginvasion, angiogenesisSand metastasis of pancreaticCcancer. Frontiers in Biosci 2008; 13(2): 440-52.

21. Olinski R, Gackowski D, Foksinski $M$, Rozalski $R$, Roszkowski K, Jaruga P. Oxidative DNA damage: assessment of the role in carcinogenesis, atherosclerosis and acquired immunodeficiency syndrome. Free Radical Bio Med 2002; 33(9): 192-200.

22. Dhananjaya $S$ and Aparna K. Current status of Cancer burden: Global and Indian scenario. Biomed Res J 2014; 1(1): 1-5.

23. Ravindranath $\mathrm{MH}$, Ramasamy V, Moon S, Ruiz C, Muthugounder S. DifferentialLgrowth suppressionNof human melanomAcells by tea (Camellia sinensis)Eepicatechins (ECG, EGC and EGCG). E-Cam 2009; 6: 523-30.

24. Huang HP, Shih YW, Chang YC, Hung CN, Wang CJ. ChemoOinhibitory

effectTof mulberryYanthocyaninson melanomaAmetastasis involved in the Ras/PI3K pathway. J Agri Food Chem 2008; 56(19): 9286-93.

25. Chen PN, Hsieh YS, Chiou HL, Chu SC. SilibininNinhibits cell invasionNthrough inactivationNof both PI3K-Akt and MAPK signalingGpathways. Chemico Biologica Interactions 2005; 156(2-3):141-50.

26. Vieira JRC, De Souza IA, Do Nascimento SC, Leite SP. IndigoferaAsuffruticosa:

an alternativeEanticancertherapy. E-Cam 2007; 4(3): 355-9.

27. Vijayalakshmi A, Masilamani K, Nagarajan E and Ravichandiran $V$. In vitro antioxidant and anticancer activity of flavonoids from Cassia Tora linn. leaves against human breast carcinoma cell lines. Der Pharma Chemica 2015;7(9):122-29.
28. Sandhia . K. G, Bindu A. R. Phytochemical, Antiinflammatory and in vitro anticancer activities of Caesalpiniabunduc stem bark. Int J Pharma Sci and Res 2015; 6(1): 50-56.

29. Khan PK, Sinha SP. Antimutagenic profile of antioxidant vitamins in drosophila mutation test. Biomed Environ Sci 2008; 21: 163-6.

30. Yahaya G, Faten AE, Fred W, Hany AES. Phytochemical screening, antioxidant activity and in vitro anticancer potential of ethanolic and water leaves extracts of Annona muricata (Graviola). Asian Pac J Trop Med 2014; 7(1): 355-63.

31. Hirano TK, Oka M, Akiba M. Antiproliferative effect of synthetic and naturally occurring flavonoids on tumour cells of human breast carcinoma cell lines, ZR75-1. Res Commun Chem Pathol Pharmacol 1989; 64: 69-78.

32. Farkhondeh $\mathrm{N}$, Abbas $A D$, Bahman $E$, Vahid $M$ and Sepideh $M$. Cytotoxic properties of some medicinal plant extracts from mazandaran, Iran. Iran Red Crescent Med J 2013;15(11):8871.

33. Barrales Cureño HJ, Reyes Reyes C, Cortez Ruiz JA, Luna Cruz A , Andrade Hoyos P4 , E. Zaragoza Ruiz E et al. Current applications of MTT assays conducted under microscopic cytotoxicity analysis in cancerous cells by using therapeutic agents of plant origin; Microscopy and imaging science: practical approaches to applied research and education. (Cited on 29.03.2018) Available on: http://www.microscopy7.org/book/81-88.pdf.

34. Senthilkumar R, Manivannan R, Balasubramaniam A, Sivakumar T, Rajkapoor B. Effects of ethanol extract of Pisonia aculeate Linn. on ehrlich ascites carcinoma tumour bearing mice. Int J Green Pharm 2008; 2(1): 50-3.

35. Jostein D, Egil K, Trond S. Bystander effects in UVinduced genomic instability: Antioxidants inhibit delayed mutagenesis induced by ultraviolet $A$ and $B$ radiation. J Carcinogenesis 2005; 4(11): 1-9.

36. Demetrios S, Spyridon O, Demetrios K. Plant phenolics protect from bleomycin-induced oxidative stress and mutagenicity in Salmonella typhimurium TA102. Anticancer Research 2004; 24(2B):743-6. 